\title{
The Role of Protein Interaction Motifs in Regulating the Polarity and Clustering of the Metabotropic Glutamate Receptor mGluR1a
}

\author{
Sonal S. Das and Gary A. Banker \\ Center for Research on Occupational and Environmental Toxicology, Oregon Health and Science University, Portland, Oregon 97239
}

\begin{abstract}
When expressed in cultured hippocampal neurons, the metabotropic glutamate receptor mGluR1a is polarized to dendrites and concentrated at postsynaptic sites. We used a mutational analysis to determine how previously identified protein interaction motifs in the C terminus of mGluR1a contribute to its localization. Our results show that the polyproline motif that mediates interaction with Homer family proteins is critical for the synaptic clustering of mGluRla. A single point mutation in this motif, which prevents the binding of Homer with mGluR1a, reduced its colocalization with a postsynaptic marker to near-chance levels but did not affect its dendritic polarity. In contrast, deleting the PDZ (postsynaptic density-95/Discs large/zona occludens-1) binding domain, which interacts with Tamalin and Shank, had no effect on synaptic localization. Neither of these protein interaction motifs is important for trafficking to the plasma membrane or for polarization to dendrites. Although deleting the entire $C$ terminus of mGluRla only modestly reduced its dendritic polarity, this domain was sufficient to redirect an unpolarized reporter protein to dendrites. These observations suggest that mGluR1a contains redundant dendritic targeting signals. Together, our results indicate that the localization of mGluR1a involves two distinct steps, one that targets the protein to dendrites and a second that sequesters it at postsynaptic sites; different protein interactions motifs mediate each step.
\end{abstract}

Key words: trafficking; Homer; PDZ-binding domains; glutamate receptor; neuronal polarity; receptor localization

\section{Introduction}

Neurons are geometrically complex cells whose surface membrane is an intricate mosaic of molecularly specialized domains. Two rather different approaches have been used to elucidate the cell biological mechanisms that underlie membrane protein localization in neurons. Those who are primarily interested in how proteins are targeted to dendrites or to the axon have used mutational strategies to identify motifs that are required for protein polarization (Horton and Ehlers, 2003). It remains to be determined what "adaptor" proteins recognize these localization signals. Those who are primarily interested in how proteins are localized to synaptic sites have focused on identifying interacting proteins. This approach has led to the identification of dozens of "scaffolding" proteins, but it has been difficult to elucidate the precise role these proteins play in receptor trafficking and localization (Kim and Sheng, 2004; Kneussel, 2005).

Received March 8, 2006; revised June 9, 2006; accepted June 18, 2006.

This work was supported by National Institutes of Health Grant MH66179. We thank B. Smoody for the preparation of neuronal cultures and G. Westbrook and R. Tsien for providing constructs. S. Kaech, L. Copenagle, J. Luisi Harp, and C. Selph provided insightful comments on this manuscript.

Correspondence should be addressed to Dr. Gary Banker, Center for Research on Occupational and Environmental Toxicology, Oregon Health and Science University, Mail Code L-606, 3181 SW Sam Jackson Park Road, Portland, OR 97239. E-mail: bankerg@ohsu.edu.

S. S. Das's present address: Department of Physiology and Biophysics, University of Washington, Seattle, WA 98195-7290.

D0I:10.1523/JNEUROSCI.1015-06.2006

Copyright $\odot 2006$ Society for Neuroscience $\quad$ 0270-6474/06/268115-11\$15.00/0
The present study uses the mutational approach favored by those who study neuronal polarity to analyze the localization of group I metabotropic glutamate receptors (mGluRs), G-protein-coupled receptors that are polarized to dendrites and clustered at postsynaptic sites (Baude et al., 1993; LopezBendito et al., 2002; Ferraguti et al., 2004). Several proteins bind to the cytoplasmic tail of group I mGluRs. Homer, a postsynaptic scaffolding protein, binds to a polyproline motif $\sim 50$ residues upstream of the $C$ terminus (Brakeman et al., 1997; Tu et al., 1998; Xiao et al., 1998). In heterologous systems, coexpressing Homer with group I mGluRs leads to receptor clustering (Tadokoro et al., 1999; Ciruela et al., 2000). In cultured hippocampal neurons, the mobility of expressed, extrasynaptic mGluR5 within the plasma membrane increases when the polyproline interaction motif is mutated, suggesting that Homer anchors mGluR5 to the underlying cytoskeleton (Serge et al., 2002). Long splice variants of group I mGluRs (Hermans and Challiss, 2001) also contain a PDZ [postsynaptic density-95 (PSD-95)/Discs large/zona occludens-1]binding domain that mediates interactions with two other scaffolding proteins, Tamalin and Shank (Tu et al., 1999; Kitano et al., 2002). Tamalin binds to PSD-95 (Kitano et al., 2003) and also interacts with proteins implicated in trafficking, including MINT2 and GRP-1 (Kitano et al., 2003). Shank binds Homer and, like Homer, is a component of the postsynaptic density. Homer and Tamalin have also been implicated in the trafficking of receptors between cell body and neurites 
(Ango et al., 2000, 2002; Ciruela et al., 2000; Kitano et al., 2002).

The present study analyzes the role of these C-terminal protein interaction motifs in localizing mGluRla in hippocampal pyramidal neurons, cells that normally do not express this protein but do express mGluR5 and all three of the group I mGluR binding proteins: Tamalin, Shank, and members of the Homer family (Baude et al., 1993; Tu et al., 1998, 1999; Naisbitt et al., 1999; Kitano et al., 2002; Ferraguti et al., 2004). mGluRla forms homodimers but does not heterodimerize with mGluR5 or with other mGluR1 splice variants (Romano et al., 1996; Robbins et al., 1999). This circumvents a key limitation in using the mutational approach to study receptor localization, the formation of multimers between transfected mutant subunits and endogenously expressed wild-type subunits (Ruberti and Dotti, 2000). We found that mutating the polyproline sequence that mediates interaction with the Homer family of proteins eliminated the clustering of mGluRla at synaptic sites but did not affect its polarization to dendrites. Deleting the PDZ-binding domain did not affect either dendritic localization or receptor clustering.

\section{Materials and Methods}

DNA constructs. The pJPA expression vector was used for all constructs in this study (J. Adelman, Oregon Health and Science University, Portland, OR). Wild-type rat mGluR1a was obtained from G. Westbrook (Vollum Institute, Oregon Health and Science University). A sequence encoding cyan fluorescent protein (CFP) or mCherry (R. Tsien, University of California San Diego, La Jolla, CA) was inserted into the wild-type cDNA following the predicted signal sequence (Masu et al., 1991) at the Eco47III site. mGluRla $(\Delta \mathrm{CT})$ was made by truncating the wild-type mGluRla after amino acid 848 ( 8 amino acids following the predicted seventh transmembrane domain). mGluRla( $\triangle \mathrm{PDZ})$ was truncated at amino acid 1196, which removes the type I PDZ-binding motif (amino acids 1197-1199) that interacts with Tamalin and Shank (Kitano et al., 2002). The mGluRla mutant that is unable to interact with endogenous Homer, mGluR1a(F1156R), was made by mutating amino acid 1156 from phenylalanine to arginine (Tu et al., 1998). CD8 $\alpha$ wild-type cDNA was manipulated to make a truncated $\mathrm{CD} 8 \alpha$ that ended 6 amino acids after the transmembrane domain (amino acids 1-216). PCR-amplified wild-type and mutant mGluR1a C termini were inserted in frame with the truncated $\mathrm{CD} 8 \alpha$ to generate the following chimeric constructs: pJPA5 CD $8 \alpha-$ mGluR1a(wild-type), $\quad$ CD $8 \alpha-$ mGluR1a(F1156R), $\quad$ CD $8 \alpha-$

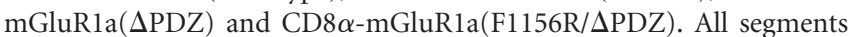
generated by PCR were sequence verified. As a control for synaptic colocalization studies, pJPA5 NR1-1a was cotransfected with pJPA5 CFPNR2A (G. Westbrook). CFP was inserted following the predicted signal sequence.

Cell culture and transfection. Primary hippocampal neuronal cultures were prepared as described previously (Goslin et al., 1998). Briefly, hippocampi were dissected from rats on embryonic day 18. These hippocampi were then dissociated and plated onto coverslips treated with poly-L-lysine at a density of $50-100$ cells $/ \mathrm{mm}^{2}$ and cultured over a monolayer of astrocytes. Cells were maintained in Neurobasal media supplemented with B27 and Glutamax (Invitrogen, Carlsbad, CA). After $8-10 \mathrm{~d}$ in culture, neurons were cotransfected with the appropriate receptor construct together with soluble yellow fluorescent protein (YFP) (to visualize cell morphology) using Lipofectamine 2000 transfection reagent (Invitrogen).

Antibodies. mGluRla constructs were detected using mixed monoclonal antibodies that recognize green fluorescent protein (GFP) and its color variants (Roche, Indianapolis, IN). CD8 $\alpha$ constructs were detected using the mouse monoclonal antibody DK25 (1:50 dilution; DakoCytomation, Carpinteria, CA). Endogenous Homer protein was detected using a rabbit polyclonal antibody that recognizes the long form of all family members, including splice variants (sc-15321, 1:100 dilution; Santa Cruz Biotechnology, Santa Cruz, CA). Other synaptic proteins were localized using antibodies against synapsin I (1:100 dilution; Syn- aptic Systems, Gottingen, Germany) and PSD-95 (clone 6G6-1C, 1:100 dilution; Affinity BioReagents, Golden, $\mathrm{CO}$ ). Biotinylated and cyanine 3 (Cy3)-conjugated secondary reagents and Cy3-conjugated streptavidin were from Jackson ImmunoResearch (West Grove, PA). Alexa633- and Alexa546-conjugated secondary reagents were from Invitrogen. Secondary antibodies were all used at a dilution of 1:1000.

Immunofluorescence staining. For most experiments, living neurons were immunostained to detect only the expressed mGluRla present on the cell surface. Cells were incubated with antibodies against the extracellular GFP epitope at $37^{\circ} \mathrm{C}$ for $5-10 \mathrm{~min}$ in Neurobasal medium. Coverslips were rinsed briefly in PBS and then fixed in $4 \%$ paraformaldehyde and $4 \%$ sucrose in PBS for $20 \mathrm{~min}$ at room temperature. After fixation, coverslips were rinsed in PBS and then blocked in 0.5\% gelatin in PBS for $30 \mathrm{~min}$. For assessment of surface polarity, cells were not permeabilized before incubation with secondary antibodies. Neurons transfected with CFP-tagged constructs were treated with biotinylated donkey antimouse secondary antibody for $1 \mathrm{~h}$, washed in blocking medium, then treated with Cy3-streptavidin for 15-30 min, and washed in blocking medium for 5 min each. Coverslips were rinsed in $\mathrm{H}_{2} 0$ and mounted using ProLong Gold Anti-Fade reagent (Invitrogen). To detect CD8 chimeras, the primary anti-CD8 antibody was detected with Cy3conjugated donkey anti-mouse antibody.

For analysis of colocalization with synaptic markers, coverslips were incubated with primary antibodies to detect receptors as described above, fixed, then permeabilized with $0.25 \%$ Triton X-100 in PBS for 5 min, washed in PBS, and placed in blocking solution for $30 \mathrm{~min}$. Cultures were incubated with anti-Homer antibody for $3 \mathrm{~h}$, washed and incubated with biotinylated goat anti-mouse and Alexa633-conjugated goat antirabbit for $1 \mathrm{~h}$, washed, incubated with $\mathrm{Cy} 3$-streptavidin, and mounted as above. Cell-surface NMDA receptor localization was assessed using the extracellular CFP epitope tag in NR2A in the same manner as described above.

Microscopy. A Leica (Nussloch, Germany) microscope (DMRXA) equipped with a $40 \times$ objective (numerical aperture 0.75 ) was used to acquire all images for polarity and clustering analysis. A $63 \times$ oilimmersion objective (numerical aperture 1.32) was used to acquire images for assessing synaptic colocalization. Images were acquired with a Roper Scientific (Tucson, AZ) Micromax 5 MHz-1300Y using MetaMorph image acquisition and analysis software (Molecular Devices, Downington, PA).

Quantification of receptor polarity. The degree to which expressed constructs were polarized was measured using the methods described by Sampo et al. (2003). Briefly, cells to be analyzed were selected using the soluble YFP fill and included in the analysis only when it was certain that all labeled neurites arose from the cell in question, not another nearby cell. Cells that expressed constructs at very high levels were excluded from analysis, because such cells often exhibited a less polarized distribution of the expressed wild-type protein (supplemental Fig. S1, available at www.jneurosci.org as supplemental material) (Silverman et al., 2005). Images included the cell body, all dendrites, and a representative sample of the primary axon and branches thereof. This typically required capturing 9-18 overlapping images in each of three channels (YFP, Cy3/ Alexa546, and phase contrast). Axons and dendrites were identified using morphological criteria based on the soluble YFP fill (see Figs. 1a, 4a,c) (Sampo et al., 2003). Dendrites emerge gradually from the cell body, taper with distance, generally have a radial orientation, and terminate $200-300 \mu \mathrm{m}$ from the cell body. By 2 weeks in culture, pyramidal cell dendrites are studded with spines. Axons are thinner at their origin, exhibit less taper, follow a meandering course and sometimes loop back on themselves, and can extend over millimeters.

All images were corrected for camera background and uneven illumination using a shading correction. One-pixel-wide lines were drawn on the axons and dendrites of the soluble YFP image and transferred to the corresponding images of the cell-surface staining. Average intensity of surface labeling was determined for all stretches of dendrites clearly free of any recurrent axon branches and a majority of unfasciculated, single axon stretches. Antibody background staining was determined as the average signal detected in adjacent, untransfected neurons. After subtracting background, the average axon fluorescence divided by the aver- 


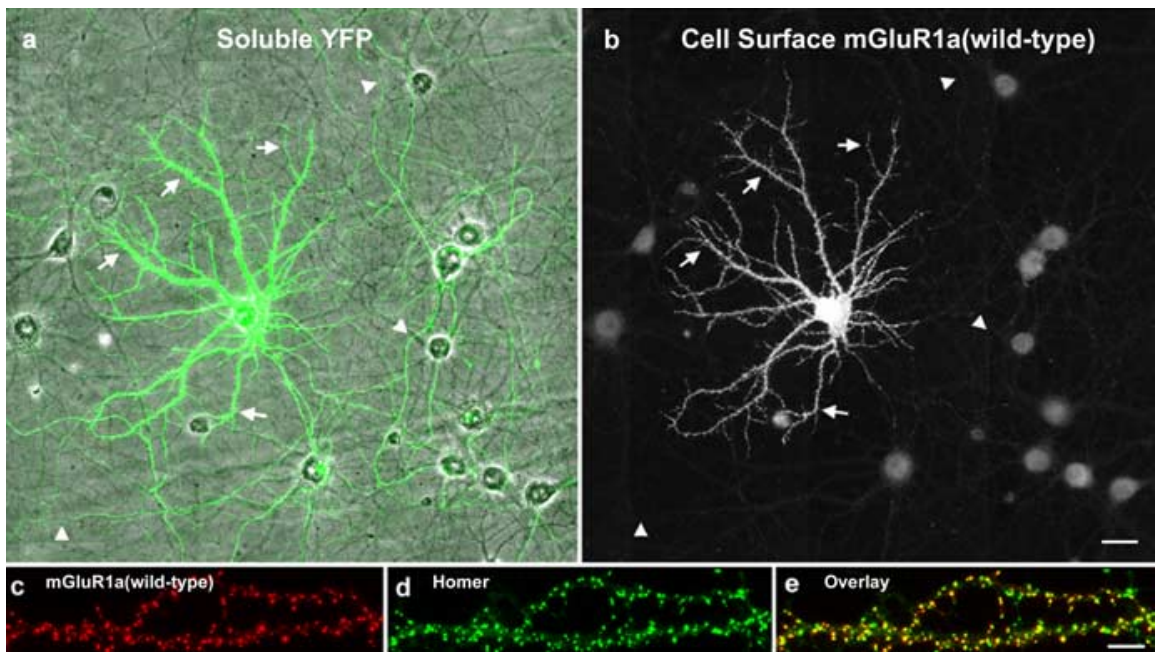

Figure 1. mGluR1a expressed in hippocampal neurons is restricted to the dendritic surface and colocalizes with a postsynaptic marker. $\boldsymbol{a}, \boldsymbol{b}$, When hippocampal neurons were cotransfected with mGluR1a and soluble YFP, the YFP was present throughout the cell ( $\boldsymbol{a}$; YFP fluorescence was pseudocolored green and overlaid over a phase-contrast image that shows all cells within the field); mGluR1a was expressed on the surface of the soma and dendrites but not the axon $(\boldsymbol{b})$. Cell bodies of nearby untransfected neurons were faintly visible, a measure of antibody background. This cell was transfected on day 9 and then stained for cell-surface receptor $5 \mathrm{~d}$ later. Arrows indicate dendrites and arrowheads the axon. $\mathbf{c}-\boldsymbol{e}$, To assess the synaptic localization of mGluR1a, cells were double stained for cell-surface mGluR1a and endogenous Homer after $21 \mathrm{~d}$ in culture. The receptor (red) appeared in distinct puncta along the surface of the dendrites $(\boldsymbol{c})$, similar to the staining pattern for Homer (green, $\boldsymbol{d})$. Overlay of the two images $(\boldsymbol{e})$ indicated that nearly every mGluR1a cluster colocalized with Homer (yellow). Scale bars: $\boldsymbol{a}, \boldsymbol{b}, 20 \mu \mathrm{m} ; \boldsymbol{c}-\boldsymbol{e}, 5 \mu \mathrm{m}$.

age dendrite fluorescence, the axon/dendrite (A:D) ratio, was used as a measure of the polarity of the expressed construct in that cell.

Quantification of receptor clustering. Segments of two separate, unfasciculated dendrites from each of the cells used for polarity analysis were selected for clustering analysis. Clusters were defined as regions along dendrites whose fluorescence intensity was twofold greater than that of the average fluorescence intensity along the whole dendrite. First, the images were thresholded to encompass all of the dendrite, then its area and average intensity above antibody background (determined as intensity in dendrites of an untransfected neighboring cell) were recorded. Next, the threshold was manually set to twice this average intensity above antibody background. Cluster area was determined as percentage area of the whole dendrite still selected under this circumstance. Cluster intensity was recorded as average intensity above antibody background. These parameters were chosen because they are independent of the size of individual clusters, which often ran together. Measurements were made by an observer who did not know which construct was being evaluated.

Quantification of synaptic colocalization. High-magnification images of cell-surface receptor (Cy3) and endogenous Homer (Alexa633) were thresholded to eliminate areas outside the dendrites. The fluorescence intensity of the two images was then compared on a pixel-by-pixel basis using correlation analysis. The resulting $r$ value serves as an unbiased measure of colocalization.

Other analyses. The level of expression of transfected mGluRla was compared with the intensity of mGluRla staining in the small population of interneurons that express this receptor endogenously (supplemental Fig. S1, available at www.jneurosci.org as supplemental material). Neurons were transfected with pJPA5 CFP-mGluR1a(wild-type) and then fixed, permeabilized, and stained with an antibody directed against the $\mathrm{C}$ terminus (Chemicon, Temecula, CA). Average fluorescence intensities in dendrites of neurons that endogenously express mGluRla or those transfected with exogenous mGluRla were determined using line scans and then corrected for antibody background. To compare cell-surface expression of the different constructs (supplemental Fig. S3, available at www.jneurosci.org as supplemental material), we determined the ratio of cell-surface receptor staining and total receptor protein (fluorescence from the CFP tag) in a boxed region over the soma.

\section{Results}

Exogenously expressed mGluR1a is restricted to hippocampal dendrites and clustered at postsynaptic sites

We first examined the localization of mGluRla (tagged with CFP in the ectodomain) that was expressed in cultured hippocampal neurons using Lipofectamine 2000. Neurons were cotransfected with soluble YFP, which fills the entire dendritic and axonal arborizations of the cell. Cultures were transfected after 7-9 d in vitro, and receptors on the cell surface were visualized 7-14 $\mathrm{d}$ later by live-cell immunostaining using an antibody that recognizes CFP. As described previously, $\sim 1 \%$ of the neurons in hippocampal cultures express mGluRla endogenously (Craig et al., 1993). As expected from studies of mGluRla localization in situ, the dendritic arbors of mGluRla-expressing neurons in culture have the features of GABAergic interneurons, as described by Benson et al. (1994). The level of expression of mGluR1a in transfected cells (identified by coexpression of soluble YFP) was roughly comparable with that in the small population of cultured neurons that expressed mGluRla endogenously, as evaluated by immunostaining with an antibody directed against the C-terminal domain (supplemental Fig. S1, available at www. jneurosci.org as supplemental material).

When exogenously expressed in hippocampal pyramidal neurons, mGluRla was present on the surface of the cell body and dendrites (Fig. 1a,b). Staining extended throughout the finest dendritic branches. At higher magnification, the staining formed discrete clusters along the dendrites (Fig. 1c). Comparison with the soluble YFP image indicated that some of these puncta were on dendritic shafts, whereas others were localized to the tips of dendritic spines (supplemental Fig. S2, available at www. jneurosci.org as supplemental material). Staining also was present along the proximal $10-30 \mu \mathrm{m}$ of the axon (i.e., along the initial segment). The remainder of the axon, which was seen clearly with the soluble YFP, was unstained for mGluRla. In mGluR1a-expressing interneurons, the receptor was also restricted to the cell body and dendrites, as described previously (Craig et al., 1993). These results suggest that the mechanisms underlying the dendritic localization of mGluR1a are shared by both pyramidal and nonpyramidal neurons, although pyramidal neurons do not normally express this receptor.

In preliminary experiments, we also examined the localization of mGluR1b, a short splice variant whose intracellular C-terminal domain is identical to that of mGluRla for the first 46 amino acids, which is followed by a unique 20 amino acid C terminus. It has been reported that mGluR1b is selectively polarized to the axon in cultured chick retinal cells, suggesting that its unique $\mathrm{C}$ terminus contains axonal targeting information (Francesconi and Duvoisin, 2002). When expressed in hippocampal pyramidal neurons, cell-surface mGluR1b was not polarized to the axon. Like mGluR1a, mGluR1b was most concentrated in the somatodendritic domain, with only weak staining detected in the axon (data not shown). This is consistent with several studies showing 
that, in tissue sections, mGluR1b immunostaining is restricted to the somatodendritic domain (Mateos et al., 1998, 2000; Alvarez et al., 2000). In light of these preliminary results, we focused the remainder of our analysis on mGluRla.

To determine whether the mGluRla puncta were localized at synaptic sites, we examined cells after $21 \mathrm{~d}$ in culture, when synapses are mature. Neurons were costained with antibodies against Homer or PSD-95, which mark excitatory postsynaptic sites (Rao et al., 1998; Shiraishi et al., 2003). We confirmed that both Homer and PSD-95 were suitable synaptic markers, based on their close apposition to synapsin I-positive presynaptic terminals (data not shown). As shown in Figure $1 c-e$, the mGluRla puncta also stained brightly for endogenous Homer. Not all Homer puncta contained mGluRla, but nearly every mGluRla cluster was also positive for Homer. A similar pattern of colocalization was found with PSD-95 (data not shown). Thus, the localization of exogenously expressed mGluR1a is comparable with that of mGluR5, the predominant group I mGluR that is endogenously expressed in pyramidal neurons (Lopez-Bendito et al., 2002).

\section{mGluR1a is directly targeted to dendrites}

The equilibrium distribution of mGluR1a observed several days after transfection reflects the sum of many different trafficking events: targeting along the biosynthetic pathway, anchoring, endocytosis, and possible subsequent redistribution. To determine whether mGluRla is directly targeted to dendrites, we assessed receptor localization at early times after transfection. mGluRla could be consistently detected on the cell surface as early as $8 \mathrm{~h}$ after transfection (data not shown), and staining intensity increased steadily over the next $16 \mathrm{~h}$. At $8 \mathrm{~h}$ after transfection, the receptor was already fully polarized on the cell surface (data not shown); no labeling of the axon surface could be detected. This finding argues against the possibility that newly synthesized mGluRla is delivered to the surface of both axons and dendrites but selectively stabilized only on the dendritic surface.

To determine whether the carriers that contain mGluRla enter the axon, we expressed mGluRla tagged with mCherry (a monomeric red fluorescent protein) (Shaner et al., 2004) to visualize intracellular compartments that contain mGluR1a en route to the plasma membrane along with cell-surface receptor. Like the cell-surface receptor, mCherry-mGluRla fluorescence was restricted to dendrites (Fig. 2). By $8 \mathrm{~h}$ after transfection, mCherry-mGluRla had reached even the most distal dendrites, but fluorescence was absent from the axon beyond its proximal segment (Fig. $2 c-f$ ). At higher magnification, mGluRla fluorescence appeared to consist of densely packed granules within the dendritic shaft. No labeled organelles could be detected in the axon. These data indicate that the transport carriers that deliver mGluRla to the cell surface are excluded from the axon. Similar results have been observed for several other dendritically polar- ized proteins (Burack et al., 2000; Silverman et al., 2001, 2005; Cheng et al., 2002; Rosales et al., 2005).

\section{The C-terminal domain of mGluRla contains a dendritic localization signal}

We used two complementary approaches to evaluate the role of protein interaction motifs within the C-terminal domain of mGluRla in governing the dendritic localization of the protein. We mutated or deleted residues to determine whether these motifs were required for dendritic localization, and we appended C-terminal sequences to an unpolarized reporter protein to determine whether they were sufficient to redirect the reporter to the dendrites. First, we expressed mGluRla constructs (tagged with CFP) with mutations in the protein interaction domains that mediate binding to Homer, Tamalin, and Shank (Fig. 3). Although these proteins were first identified as synaptic scaffolding proteins, considerable evidence suggests that such proteins also play a role in receptor trafficking (Kneussel, 2005). These mutations have been shown previously to disrupt interactions with the respective proteins in biochemical assays (Tu et al., 1998, 1999; Kitano et al., 2002). The level of expression of each construct (both CFP fluorescence to assess total protein levels and live-cell immunostaining to assess surface expression) was evaluated to determine whether they trafficked normally to the cell surface (supplemental Fig. S3, available at www.jneurosci.org as supplemental material). Each of the constructs expressed at approximately the same level as wild-type mGluRla.

Figure $4, a$ and $b$, illustrates the localization of 


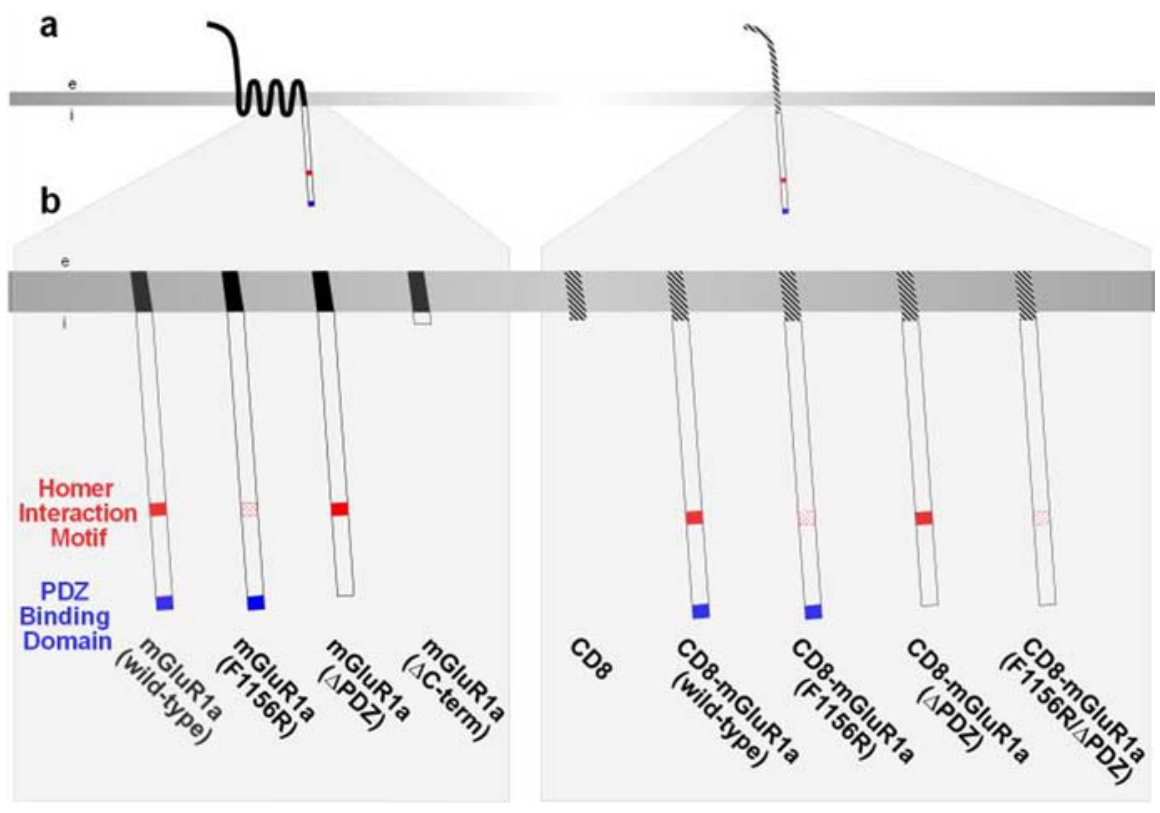

Figure 3. The mGluR1a constructs used in these experiments. a shows the topology of mGluR1a (left) and CD8 (right). $\boldsymbol{b}$ shows a schematic representation of the C terminus of mGluR1a in the context of the full-length receptor (left) and in chimeras in which it was linked to the ectodomain and transmembrane domains of CD8 (right). The Homer interaction motif is indicated by the red bar, and the PDZ-binding domain is indicated by the blue bar. The entire ( terminus is 359 amino acids in length, $\mathrm{mGluR1a}(\Delta \mathrm{CT})$ was truncated 8 amino acids following the seventh transmembrane domain, mGluR1a(F1156R) contains a mutation in the polyproline motif that abolishes its binding to Homer, and mGluR1a( $\triangle P D Z)$ lacks the final 3 amino acids, which mediate interactions with the PDZ domains of Shank and Tamalin. These three C-terminal mutations were also appended to CD8. An additional CD8-mGluR1a chimera included mutations of both protein interaction motifs.

mGluR1a(F1156R), which is unable to interact with Homer. This mutant receptor was highly polarized to dendrites, like wild-type mGluRla (compare with Fig. $1 a, b)$. mGluRla $(\Delta \mathrm{PDZ})$, which lacks the PDZ-binding motif, was also restricted to the somatodendritic domain. Because previous results suggest that the C-terminal domain of mGluRla is essential for its dendritic localization in the retina (Francesconi and Duvoisin, 2002), we also examined the localization of mGluRla $(\Delta \mathrm{CT})$, which lacks the entire $\mathrm{C}$ terminus (Fig. $4 c, d$ ). This construct was also polarized to the somatodendritic cell surface; cell-surface staining was bright in all dendrites, and only faint staining was detected along axonal branches, extending to the tips of some, but not all, axonal growth cones.

The cell-surface polarity of each construct was quantified by calculating the A:D ratio: the average fluorescence intensity in the axon divided by the average fluorescence intensity in the dendrites of the same cell (Sampo et al., 2003). The regions to be analyzed were selected based on the soluble YFP fill to ensure that representative regions throughout the axon and dendrites were sampled in an unbiased manner. The results of this analysis are shown in Figure 5. The A:D ratio for wild-type mGluRla was 0.11 , comparable with that of the low-density lipoprotein receptor (LDLR), a control dendritic protein included in our experiments, as well as several other dendritic membrane proteins (Jareb and Banker, 1998; Cheng et al., 2002; Silverman et al., 2005). We also determined the A:D ratio for the short splice variant mGluR1b, which averaged $0.33(n=6)$. Thus, mGluR1b was somewhat less concentrated in the dendrites than mGluR1a but was not polarized to the axon, as reported for cultured retinal neurons (Francesconi and Duvoisin, 2002). Mutations to either the Homer or Tamalin interaction domains had no significant effect on dendritic localization [mGluR1a(F1156R), A:D ratio of
0.09; mGluR1a( $\Delta$ PDZ), A:D ratio of 0.13 ]. Truncation of the entire $\mathrm{C}$ terminus caused a small but statistically significant reduction in polarity compared with mGluRla(wild-type) [mGluRla $(\Delta \mathrm{CT})$, A:D ratio of $0.21 ; p<0.001]$. In contrast, mutating the dendritic localization signal in LDLR increased its A:D ratio to 0.69, comparable with that of unpolarized proteins (Jareb and Banker, 1998; Sampo et al., 2003). Together, these results show that the polyproline and PDZ-binding motifs are not necessary for the polarization of mGluRla. Deleting the entire C terminus of mGluRla caused only a modest reduction in its dendritic localization.

Although these results indicate that the $\mathrm{C}$ terminus of the receptor is not required for its polarization, they do not rule out the possibility that the cytoplasmic tail contains a redundant signal that might be sufficient for dendritic localization. To examine this possibility, we asked whether the $\mathrm{C}$ terminus of mGluRla could redirect $\mathrm{CD} 8 \alpha$, an unpolarized reporter protein (Craig et al., 1995). We prepared chimeras consisting of the ectodomain and transmembrane domain of CD8 linked to the C-terminal cytoplasmic domain of mGluRla. When this chimeric protein was expressed in hippocampal neurons, it was highly enriched on the dendritic surface (Fig. 6b), with an A:D ratio identical to that of full-length mGluRla (average A:D ratio of 0.11) (Fig. 7). CD8 without the C terminus of mGluR1a was present throughout both axons and dendrites (Fig. 6a), with an average $\mathrm{A}: \mathrm{D}$ ratio of 1.10 .

Because the CD8-mGluRla chimera was highly polarized, we next asked whether mutation of either the Homer interaction motif or the PDZ-binding domain altered the localization of the CD8 chimera. Mutation of either motif caused a modest, marginally significant reduction in the A:D ratios of the chimeras [CD8mGluR1a(F1156R), A:D ratio of 0.24; CD8-mGluR1a( $\Delta$ PDZ), $A: D$ ratio of 0.24$]$. Simultaneously disrupting both interaction motifs did not lead to an additional decrease in A:D ratio [CD8mGluRla(F1156R/DPDZ), A:D ratio of 0.23]. A mutation that disrupted a dendritic localization signal would be expected to reduce polarity to a much greater extent, essentially to the level of CD8 alone. It may be that mutations in the protein interaction motifs lead to small, generalized changes in secondary structure that affect interactions mediated by other motifs within the $\mathrm{C}$ terminus.

These experiments indicate that the $\mathrm{C}$ terminus of mGluRla contains dendritic localization information, but, in the absence of the $\mathrm{C}$ terminus, other regions of the receptor are also capable of maintaining dendritic polarity to a large degree. Dendritic localization is essentially independent of both the polyproline and PDZ interaction motifs contained in the carboxyl tail of the receptor.

\section{The polyproline motif that binds Homer is required for the synaptic clustering of mGluRla}

Previous studies have suggested that both Homer and Shank play a role in scaffolding type 1 metabotropic glutamate receptors 
because coexpression of these proteins with mGluRs enhances receptor clustering in heterologous cells (Ciruela et al., 1999, 2000; Tadokoro et al., 1999; Tu et al., 1999). To determine whether the synaptic clustering of mGluRla in hippocampal neurons involves interactions with these proteins, we determined the extent to which the constructs described were synaptically clustered. Figure 8 illustrates high-magnification images of representative cells expressing each of these constructs. As described above, wild-type mGluRla was present in discrete clusters along the dendrites (Fig. 8a) (see also Fig. $1 c-e)$. Very little receptor staining was observed between clusters. Truncation of the C-terminal domain of mGluRla greatly reduced receptor clustering. Diffuse staining of mGluRla $(\Delta C T)$ was seen all along the dendritic shafts and filled the spines entirely rather than only labeling spine tips (Fig. 8b). As a negative control, we also evaluated the localization of LDLR(Y3A), an unpolarized protein that is uniformly distributed on the dendritic surface (Fig. 8e). The staining pattern of mGluRla $(\Delta \mathrm{CT})$ resembled that of $\operatorname{LDLR}(\mathrm{Y} 3 \mathrm{~A})$.

Next we asked whether mutations in specific protein interaction domains of mGluRla could account for the disruption in clustering seen after truncation of the $\mathrm{C}$ terminus. Truncation of the carboxyl PDZ-binding motif of the receptor had relatively little effect. mGluRla $(\triangle \mathrm{PDZ})$ was present in clusters along dendritic shafts and spines (Fig. $8 d$ ), similar to mGluRla(wildtype). In marked contrast, mutation of the polyproline motif that mediates Homer binding disrupted clustering (Fig. $8 c$ ), resulting in an expression pattern similar to that of mGluRla $(\Delta \mathrm{CT})$.

We used two complementary methods to quantify these results: one to assess the extent to which receptors were concentrated in clusters, the other to evaluate the degree to which receptors colocalized with a postsynaptic marker. In the first method, a computer-based algorithm was used to identify receptor clusters (defined as regions in which the fluorescence intensity was at least twice that of the average fluorescence intensity over the entire dendrite) (supplemental Fig. S4, available at www.jneurosci.org as supplemental material). We then computed two measures of the extent of receptor clustering: cluster area (defined as the fraction of the dendritic surface occupied by clusters) and cluster intensity (defined as the average pixel intensity within clusters divided by the average pixel intensity of the regions between clusters). Cluster size and cluster number were not assessed because clusters sometimes ran together, making it difficult to define individual clusters. The results of this analysis are shown in Figure 8. When wild-type mGluR1a was expressed, almost $9 \%$ of the dendritic surface was occupied by clusters and the fluorescence intensity within clusters was 4.4 times greater than in regions

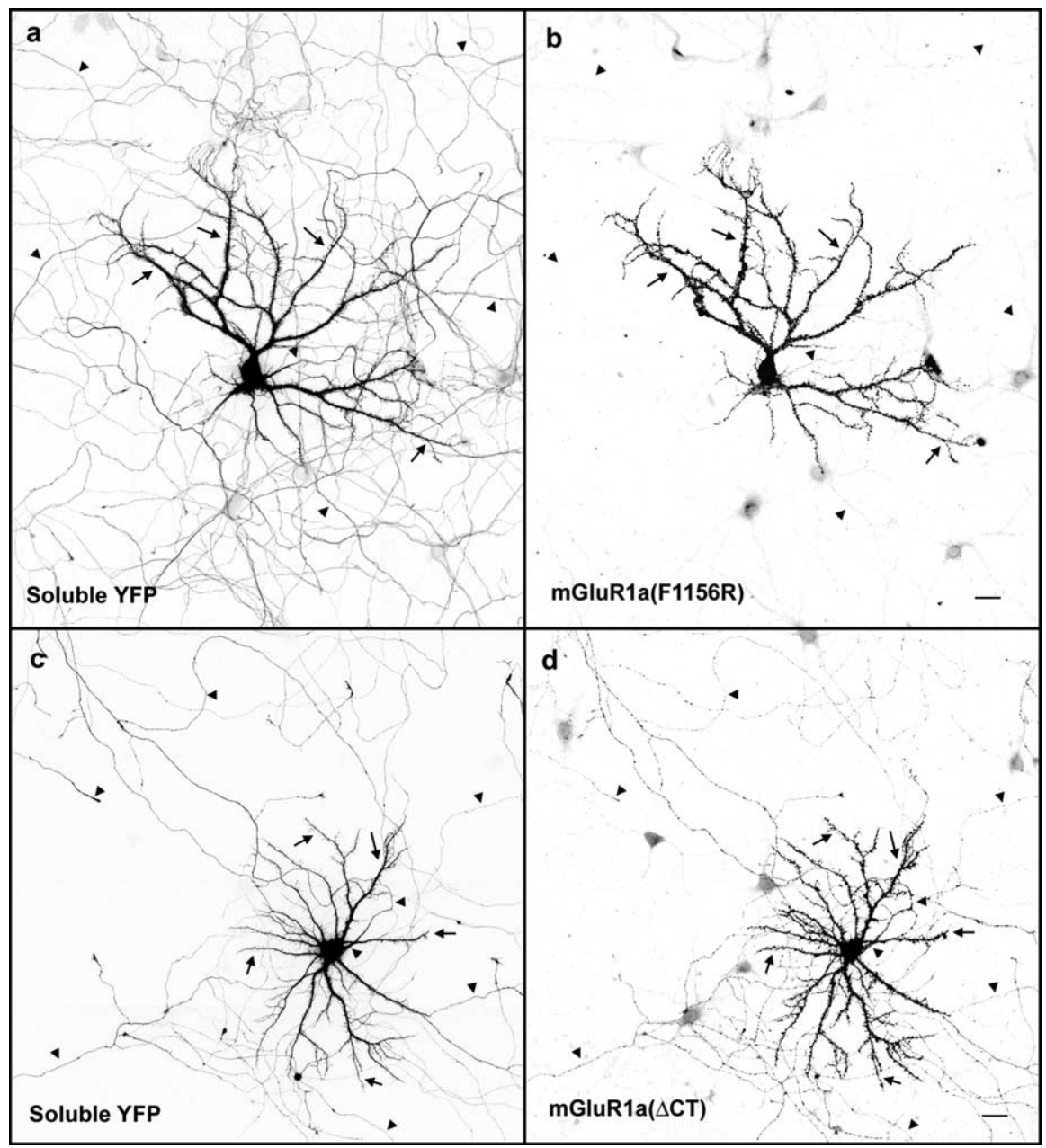

Figure 4. The C terminus of mGluR1a is not required for dendritic polarization. To assess the role of the C-terminal domain in bodies of nearby untransfected neurons exhibit faint background staining. Cells were transfected between 7 and $9 \mathrm{~d}$ in vitro and tion of thin axonal processes. Arrows indicate dendrites and arrowheads the axon. Scale bar, $20 \mu \mathrm{m}$.

between clusters. LDLRmutant(Y3A), a protein that would not be expected to form clusters, served as a control. Even with this protein, there were regions in which the fluorescence intensity was more than twice the average intensity (the definition of a cluster in our algorithm). On average, these regions occupied $\sim 2 \%$ of the dendritic surface and had an average intensity of 2.3 times greater than intervening regions. mGluRla $(\Delta \mathrm{CT})$ exhibited a large, statistically significant reduction in both cluster area and intensity compared with mGluRla(wild-type) $(p<0.001)$. This reduction in clustering observed after truncating the $\mathrm{C}$ terminus was entirely accounted for by a single point mutation in the polyproline interaction motif of mGluRla $[$ mGluRla(F1156R)]. Cluster area and cluster intensity of mGluRla $(\triangle \mathrm{PDZ})$ were not significantly different from that of the wild-type receptor. It is important to note that the reduction in receptor clustering observed with constructs lacking the proline interaction domain was not attributable to a reduced concentration of receptor on the cell surface: surface expression was identical to the wild-type receptor (supplemental Fig. S3, available at www.jneurosci.org as supplemental material). Rather, it 


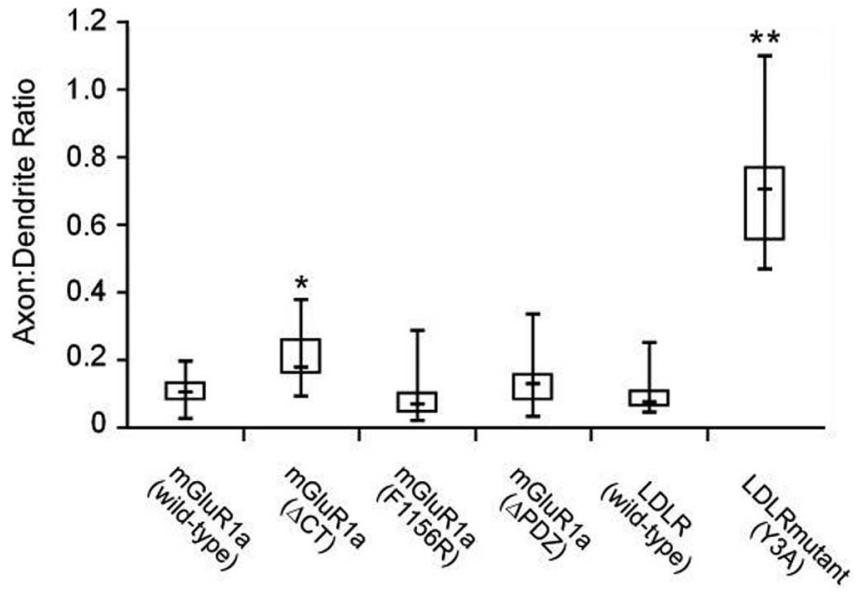

Figure 5. The effects of mutations within the C terminus of mGluR1a on receptor polarity. The axon/dendrite ratio was used to quantify polarization. Wild-type mGluR1a was highly polarized, with an A:D ratio comparable with that of LDLR, a prototypical dendritic protein. Mutations in the known C-terminus protein interaction motifs had no effect on the polarity of mGluR1a. Truncation of the entire $C$ terminus resulted in a modest but statistically significant reduction in polarity $\left({ }^{*} p<0.001\right.$, Mann-Whitney $U$ test). By comparison, mutation of the dendritic localization signal in LDLR resulted in a much greater loss in polarity $\left({ }^{* *} p<0.0001\right.$, Mann-Whitney $U$ test). These box plots show the median value (the horizontal bar within the box), the two central quartiles (the box), and the range (the vertical line). The results were derived from two to four separate experiments; $10-22$ cells were analyzed in each condition.

represented a change in the pattern of localization of surface receptor, from clustered to diffuse.

We next assessed the extent to which this set of constructs colocalized with a postsynaptic marker. Constructs were expressed in 1-week-old cells, and colocalization with endogenous Homer was quantified when cells were $21 \mathrm{~d}$ old, a stage when synapses are relatively mature. The results from these studies are illustrated in Figure 9 and quantified in Figure 10. The degree of colocalization was assessed by plotting the fluorescence intensity in the mGluR1a channel with the intensity in the Homer channel on a pixel-by-pixel basis and then calculating a correlation coefficient $(r)$. This is a very stringent measure of colocalization; $r$ values as low as 0.25 are indicative of significant correlation (Rappoport and Simon, 2003) (supplemental Fig. S5, available at www.jneurosci.org as supplemental material). As expected, fluorescence of wild-type mGluRla primarily colocalized with Homer staining (Fig. 1c-e); analysis revealed an average correlation coefficient of 0.60 . A similar value was obtained when NMDA receptor subunits were expressed and their distribution compared with endogenous Homer (correlation coefficient of 0.65) (Shiraishi et al., 2003). Truncating the entire $C$ terminus or mutating the polyproline interaction sequence of mGluR1a greatly reduced colocalization with endogenous Homer (correlation coefficients of 0.16 and 0.18 , respectively). Deleting the PDZ interaction domain had no effect on synaptic localization (correlation coefficient of 0.60 ). These results demonstrate that the polyproline interaction motif is necessary for the synaptic clustering of mGluR1a.

\section{Discussion}

In this study, we analyzed the role of known protein interaction domains in regulating the dendritic polarity and synaptic localization of the metabotropic glutamate receptor mGluRla. Our results demonstrate that the polyproline interaction motif, which mediates interaction with Homer family proteins, is critical for the synaptic clustering of mGluR1a. In contrast, the PDZ- binding domain was not required for receptor clustering. Neither protein interaction domain was important for dendritic localization. The C terminus of mGluR1a contains a dendritic localization signal that was sufficient to redirect an unpolarized protein to the dendrites, but deleting the $\mathrm{C}$ terminus of mGluR1a only modestly reduced dendritic polarity, indicating that other regions also contain a dendritic localization signal.

\section{Protein interaction motifs that govern receptor localization at postsynaptic sites}

Although many receptor scaffolding proteins have been identified, it has been difficult to define their precise role in receptor localization. The interaction between NMDA receptors and PSD-95 is a classic example. Although the two proteins interact biochemically and cocluster in heterologous systems (Kornau et al., 1995), NMDA receptors remain synaptically localized in mice with a targeted mutation in PSD-95, and mutations in the PDZbinding motif of NR2B only modestly affect receptor localization in cultured neurons (Migaud et al., 1998; Prybylowski et al., 2005). Glycine receptors and gephyrin offer a second example. Knocking out gephyrin abolishes receptor clusters on the cell surface, but it is unclear whether this reflects a defect in receptor trafficking to the plasma membrane or in anchoring at synaptic sites (Feng et al., 1998; Levi et al., 2004).

By comparison, our findings appear quite straightforward. Mutating the polyproline interaction motif in mGluR1a, which mediates interaction with Homer family proteins, reduced colocalization with a postsynaptic marker to near-chance levels. The amount of receptor present on the cell surface was unchanged; it simply became diffusely distributed. This result confirms and extends previous observations. The mobility of extrasynaptic mGluR5 within the plasma membrane, as assessed by single particle tracking, increases when the polyproline interaction motif is mutated, suggesting that Homer may anchor mGluR5 to the underlying cytoskeleton (Serge et al., 2002). Technical limitations precluded the use of single particle tracking to evaluate the role of Homer in anchoring receptors at postsynaptic sites. Although Homer is the only protein known to interact directly with mGluRla via the polyproline motif, mutating this motif could also disrupt interactions with other proteins not yet identified.

Deleting the three C-terminal residues that comprise the PDZ-binding domain of mGluR1a did not reduce synaptic clustering of the receptor. This deletion abolishes the direct interaction between group I mGluRs and Shank (Tu et al., 1999) and reduces, but does not abolish, interaction with Tamalin, which also binds other sites within the $\mathrm{C}$ terminus of mGluRla (Kitano et al., 2002; Hirose et al., 2004). Even more telling, deleting the entire $\mathrm{C}$ terminus of mGluR1a did not diminish receptor clustering or colocalization with postsynaptic markers any more than a single point mutation in the proline interaction motif. These results are somewhat surprising because PDZ interactions have long been thought to play a crucial role in linking receptors to postsynaptic scaffolding proteins (Kim and Sheng, 2004). Because mGluR1a is not normally expressed in hippocampal pyramidal neurons, it could be argued that the proteins that interact with the PDZ-binding motifs are also missing, but this possibility seems unlikely. The PDZ-binding motif present in mGluRla is conserved in mGluR5, which is highly expressed in pyramidal neurons. Moreover, the two proteins that are known to interact with the PDZ-binding motif, Tamalin and Shank, are also expressed in hippocampal pyramidal neurons (Baude et al., 1993; Tu et al., 1998, 1999; Naisbitt et al., 1999; Kitano et al., 2002; Ferraguti et al., 2004). Several other recent findings also indicate 
that binding between receptors and postsynaptic scaffolding proteins identified using biochemical approaches does not necessarily imply that these interactions are required for receptor localization in situ (Migaud et al., 1998; Kim et al., 2005; Prybylowski et al., 2005).

The role of C-terminal protein interaction motifs in the polarity and trafficking of mGluRla

We used two complementary approaches to evaluate the role of protein interaction motifs within the $\mathrm{C}$ terminus of mGluRla in localizing the receptor to dendrites. One approach was based on mutating or deleting residues within the $\mathrm{C}$ terminus, and the other was based on appending C-terminal residues to an unpolarized reporter protein. Deleting the entire $\mathrm{C}$ terminus of mGluRla caused only a modest reduction in polarity, but adding the $\mathrm{C}$ terminus effectively redirected a reporter protein to the dendrites. Previous studies concluded that the C-terminal domain is important for the dendritic localization of mGluRla in retinal neurons and of mGluR2 in hippocampal cultures (Stowell and Craig, 1999; Francesconi and Duvoisin, 2002). Our results show that the C-terminal domain of mGluRla contains a signal sufficient for dendritic localization in hippocampal neurons but indicate that other regions of the protein likely do as well. In this regard, our results parallel studies on the targeting of other G-protein-coupled receptors in polarized epithelial cells. For example, Nadler et al. (2001) identified residues within a cytoplasmic loop of the $\mathrm{M}_{3}$ muscarinic acetylcholine receptor that were sufficient to redirect $\mathrm{M}_{2}$ receptor to the basolateral domain but found that deletion of these residues did not disrupt the basolateral localization of $\mathrm{M}_{3}$ muscarinic acetylcholine receptor.

In retinal cultures, Francesconi and Duvoisin (2002) found that the short splice variant mGluR1b was polarized to the axon and that deleting the entire $\mathrm{C}$ terminus of mGluRla caused it to be polarized to the axon. This led them to propose that a dendritic targeting signal present in the distal $\mathrm{C}$ terminus of mGluRla was dominant over an axonal targeting signal present with that portion of the $\mathrm{C}$ terminus common to both splice variants. We were unable to confirm these results in cultured hippocampal neurons. Both mGluR1b and truncated mGluR1a were polarized to dendrites, not enriched in the axon. It may be that different mechanisms underlie axonal targeting in these different cell types.

Because the chimera consisting of the $\mathrm{C}$ terminus of mGluR $1 \mathrm{a}$ appended to CD8 was highly polarized to the dendrites, it was possible to evaluate the role of the known C-terminal protein interaction motifs in governing the dendritic localization of the chimera. Mutating the polyproline motif or deleting the PDZbinding domain in the CD8-mGluR1a chimera, either singly or in combination, only modestly reduced polarity. Because mutating a bona fide dendritic localization motif typically results in a complete loss in polarity (Fig. 5) (Jareb and Banker, 1998), it seems unlikely that interaction with Homer or Shank is crucial

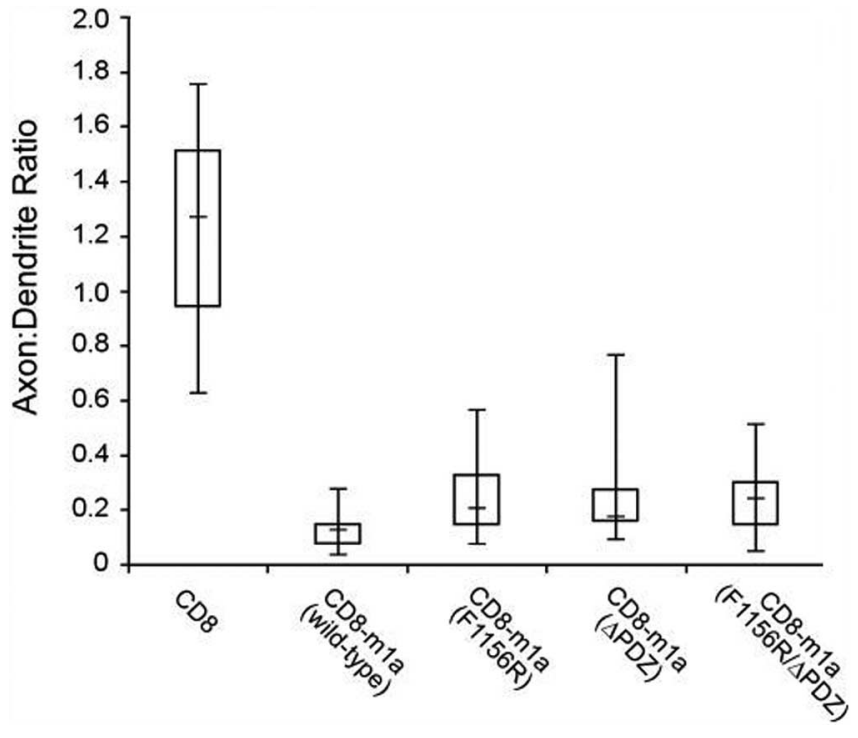

Figure 7. The polarity of CD8 - mGluR1a chimeras. CD8, used as a reporter in these experiments, was unpolarized. Appending the C terminus of wild-type mGluR1a to CD8 caused the chimeric protein to be strongly polarized to the dendrites. Mutations within specific protein interaction motifs in the C terminus of mGluR1a reduced the dendritic polarity of these chimeric molecules only slightly. All of the chimeric constructs were significantly more polarized than CD8 (Mann-Whitney $U$ test, $p<0.0001$ ). The chimeric constructs with mutations in the protein interaction motifs of mGluR1a were marginally less polarized than CD8-mGluR1a(wild-type) (Mann-Whitney $U$ test, $0.005<p<$ 0.05). The plots show the median value (the horizontal bar within the box), the two central quartiles (the box), and the range (the vertical line). The results are from three to four separate experiments; 13-17 cells were analyzed in each condition. 

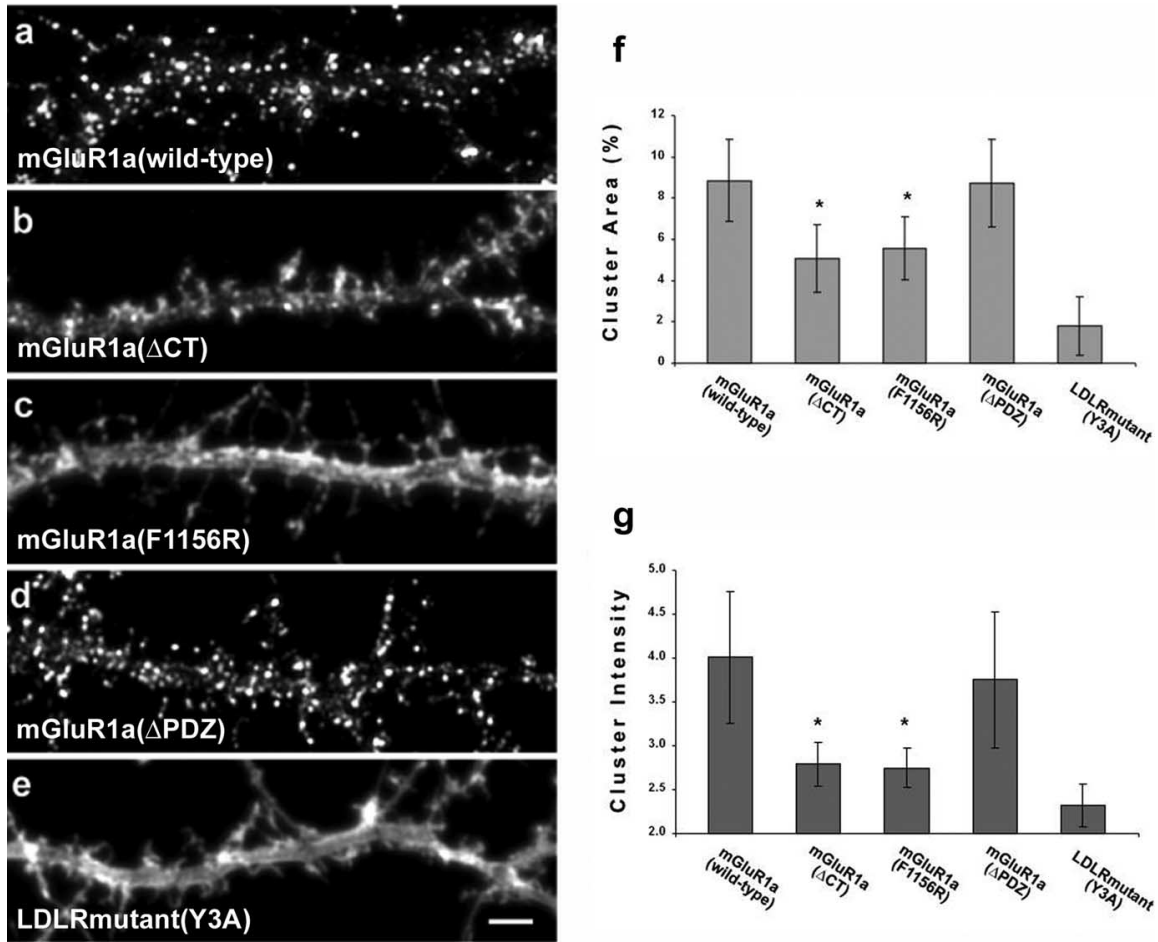

Figure 8. The Homer interaction motif is required for mGluR1a clustering. $\boldsymbol{a}-\boldsymbol{e}$, Representative images of hippocampal neurons that were cotransfected with wild-type or mutant mGluR1a constructs and subsequently immunolabeled for cell-surface receptors. mGluR1a(wild-type) was present in discrete clusters along dendritic shafts and at the tips of dendritic spines $(\boldsymbol{a})$. Deleting the $\boldsymbol{C}$ terminus $(\boldsymbol{b})$ or introducing a point mutation in the Homer interaction motif $(\boldsymbol{c})$ markedly reduced clustering, whereas deleting the PDZ-binding domain (d) had little effect. LDLR(Y3A) served as an example of a membrane protein that is not clustered on the neuronal cell surface $(\boldsymbol{e})$. Cells were transfected after 7-9 $d$ in culture and then stained for cell-surface receptor $5-7$ d later. $\boldsymbol{f}, \boldsymbol{g}$, The clustering of each construct was quantified by calculating the percentage of the cell surface occupied by clusters $(\boldsymbol{f})$ and the average cluster intensity $(\boldsymbol{g})$. Deleting the $\boldsymbol{C}$ terminal or mutating the Homer interaction domain caused a marked reduction in cluster area and cluster intensity, whereas mutating the PDZ interaction domain had no effect. The results were derived from two to four separate experiments; $16-22$ cells were analyzed for each mGluR1a construct. ${ }^{*} p<0.001, t$ test. Scale bar, $5 \mu \mathrm{m}$.

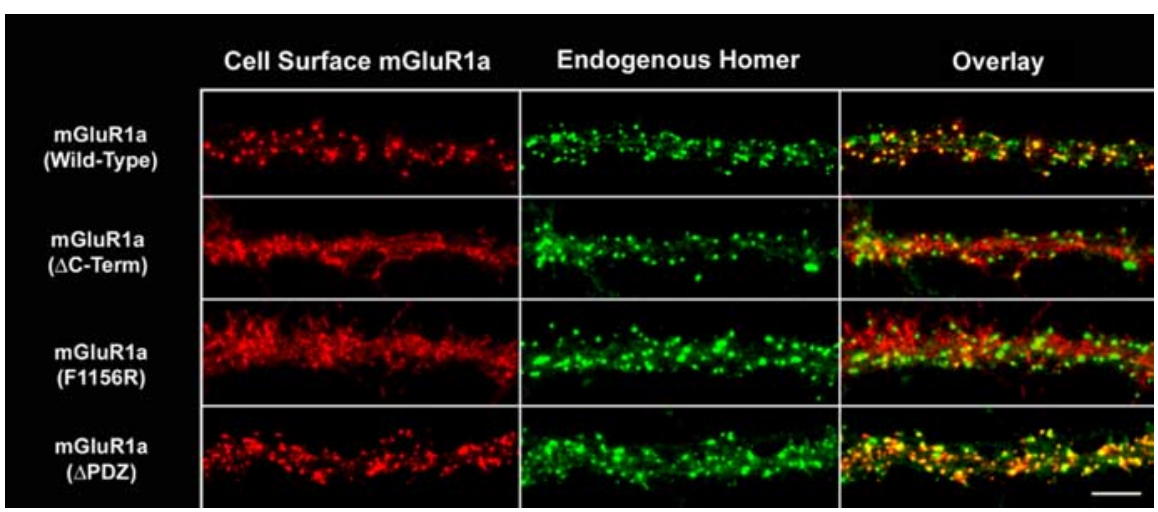

Figure 9. The polyproline interaction motif is required for the synaptic localization of mGluR1a. To determine whether protein interaction motifs within the C terminus played a role in synaptic localization, hippocampal neurons were transfected with constructs expressing wild-type or mutant mGluR1a and then stained for cell-surface receptors (red) and endogenous Homer, a postsynaptic marker (green). Deleting the entire C terminus or mutating the Homer interaction domain reduced colocalization to a similar extent, whereas deleting the PDZ interaction domain had little effect. Cells were transfected after $9 \mathrm{~d}$ in culture and then immunolabeled for cell-surface receptors and endogenous Homer $12 \mathrm{~d}$ later. Scale bar, $5 \mu \mathrm{m}$.

for dendritic localization. Francesconi and Duvoisin (2002) also found that deleting the C-terminal 128 amino acids of mGluR1a, which includes all of the sequences that interact with Tamalin (Hirose et al., 2004), did not disrupt the dendritic localization of mGluRla in retinal neurons.
Several studies suggest that Homer family proteins and Tamalin play an important role in the trafficking of group I mGluRs from the cell body out into neurites (Ango et al., 2000, 2002; Ciruela et al., 2000; Kitano et al., 2002). For example, when either mGluR1a or mGluR5 was expressed alone, the receptors could only be detected in the cell body. Coexpressing Homer $1 \mathrm{a} / \mathrm{b} / \mathrm{c}$ or Tamalin allowed the receptor to enter neurites (Ango et al., 2000, 2002; Ciruela et al., 2000; Kitano et al., 2002). It is difficult to reconcile our findings with these results. In our hands, expressed mGluRla reached the dendritic surface very efficiently without the need for coexpressing Homer or Tamalin. Moreover, mutating or deleting the domains that interact with Homer or Tamalin, or even deleting the entire C-terminal domain, did not reduce trafficking of mGluRla to the dendritic surface. Most of the evidence that favors a role for Homer in mGluR trafficking derives from studies of cultured neurons at relatively early stages of development, before the cells have acquired a mature complement of synapses. Perhaps mature hippocampal pyramidal neurons express other proteins that ensure effective receptor trafficking, even when interactions with Homer are prevented.

Separate sequences mediate dendritic polarity and synaptic clustering It has been proposed that the localization of postsynaptic receptors involves two distinct steps: first, the targeting of receptors to the somatodendritic domain, followed by the sequestration of receptors by interaction with scaffolding proteins present at synaptic sites (Craig et al., 1993). In general, our results support this model. First, our experiments demonstrate that mGluRla is directly targeted to dendrites; we were unable to obtain evidence that the receptor transiently appeared on the surface of the axon or that intracellular carriers containing the receptor are transported beyond the axon initial segment. In addition, we found that separate signals mediate the polarity and clustering of mGluR1a. Mutating the polyproline interaction motif abolishes the synaptic localization of mGluRla but does not affect its dendritic localization. This result would be expected if binding to Homer anchors mGluRla at synaptic sites. Preventing the interaction with Homer would enhance the lateral diffusion of mGluRla within the dendritic membrane, but the diffusion barrier at the axon initial segment (Winckler et al., 1999) would prevent the protein from diffusing into the axon. Conversely, studies on the localization of the excitatory amino acid trans- 


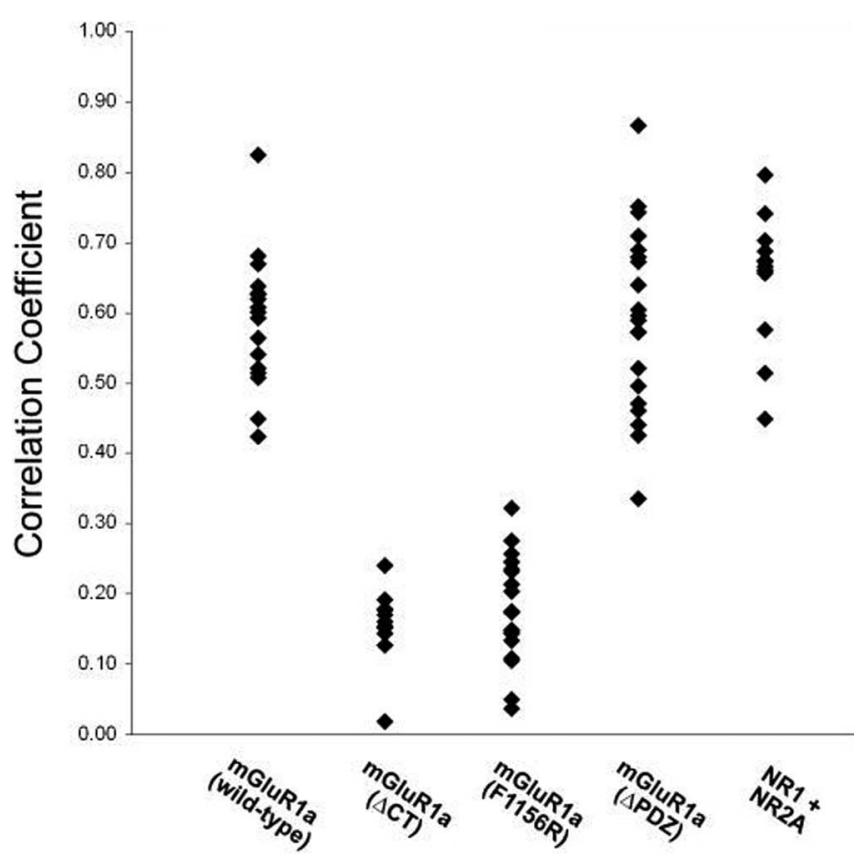

Figure 10. The effects of mutations within the C terminus of mGluR1a on colocalization with Homer. The fluorescence intensity of the wild-type receptor was highly correlated with the intensity of Homer staining (mean $r=0.60$ ). Truncating the $C$ terminus or mutating the Homer interaction motif greatly reduced the $r$ value, whereas deleting the PDZ interaction motif had no effect. For comparison, we also assessed colocalization of NMDA receptor (coexpressed NR1 + NR2A subunits) and Homer. Wild-type mGluR1a and NMDA receptors colocalized with Homer to a similar degree. The plot shows the correlation coefficient between receptor and Homer staining (for details, see supplemental Fig. S4, available at www.jneurosci.org as supplemental material). Each point represents the correlation coefficient from a single cell.

porter EAAT3 showed that mutations that disrupt its dendritic polarity do not interfere with its clustering. Thus, in the case of mGluRla, we favor a two-step model in which separate proteinprotein interactions are responsible for dendritic targeting and synaptic localization. Our results indicate that interactions with Homer localize the receptor to postsynaptic sites. It remains to be determined which "adaptor" proteins recognize the dendritic localization signals of the receptor and where along the trafficking pathway these signals act.

\section{References}

Alvarez FJ, Villalba RM, Carr PA, Grandes P, Somohano PM (2000) Differential distribution of metabotropic glutamate receptors $1 \mathrm{a}, 1 \mathrm{~b}$, and 5 in the rat spinal cord. J Comp Neurol 422:464-487.

Ango F, Pin JP, Tu JC, Xiao B, Worley PF, Bockaert J, Fagni L (2000) Dendritic and axonal targeting of type 5 metabotropic glutamate receptor is regulated by homerl proteins and neuronal excitation. J Neurosci 20:8710-8716.

Ango F, Robbe D, Tu JC, Xiao B, Worley PF, Pin JP, Bockaert J, Fagni L (2002) Homer-dependent cell surface expression of metabotropic glutamate receptor type 5 in neurons. Mol Cell Neurosci 20:323-329.

Baude A, Nusser Z, Roberts JD, Mulvihill E, McIlhinney RA, Somogyi P (1993) The metabotropic glutamate receptor (mGluR1 alpha) is concentrated at perisynaptic membrane of neuronal subpopulations as detected by immunogold reaction. Neuron 11:771-787.

Benson DL, Watkins FH, Steward O, Banker G (1994) Characterization of GABAergic neurons in hippocampal cell cultures. J Neurocytol 23:279-295.

Brakeman PR, Lanahan AA, O'Brien R, Roche K, Barnes CA, Huganir RL, Worley PF (1997) Homer: a protein that selectively binds metabotropic glutamate receptors. Nature 386:284-288.

Burack MA, Silverman MA, Banker G (2000) The role of selective transport in neuronal protein sorting. Neuron 26:465-472.

Cheng C, Glover G, Banker G, Amara SG (2002) A novel sorting motif in the glutamate transporter excitatory amino acid transporter 3 directs its targeting in Madin-Darby canine kidney cells and hippocampal neurons. J Neurosci 22:10643-10652.

Ciruela F, Soloviev MM, McIlhinney RA (1999) Co-expression of metabotropic glutamate receptor type 1alpha with homer-1a/Vesl-1S increases the cell surface expression of the receptor. Biochem J 341:795-803.

Ciruela F, Soloviev MM, Chan WY, McIlhinney RA (2000) Homer-1c/ Vesl-1L modulates the cell surface targeting of metabotropic glutamate receptor type lalpha: evidence for an anchoring function. Mol Cell Neurosci 15:36-50.

Craig AM, Blackstone CD, Huganir RL, Banker G (1993) The distribution of glutamate receptors in cultured rat hippocampal neurons: postsynaptic clustering of AMPA-selective subunits. Neuron 10:1055-1068.

Craig AM, Wyborski RJ, Banker G (1995) Preferential addition of newly synthesized membrane protein at axonal growth cones. Nature 375:592-594.

Feng G, Tintrup H, Kirsch J, Nichol MC, Kuhse J, Betz H, Sanes JR (1998) Dual requirement for gephyrin in glycine receptor clustering and molybdoenzyme activity. Science 282:1321-1324.

Ferraguti F, Cobden P, Pollard M, Cope D, Shigemoto R, Watanabe M, Somogyi P (2004) Immunolocalization of metabotropic glutamate receptor 1alpha (mGluRlalpha) in distinct classes of interneuron in the CA1 region of the rat hippocampus. Hippocampus 14:193-215.

Francesconi A, Duvoisin RM (2002) Alternative splicing unmasks dendritic and axonal targeting signals in metabotropic glutamate receptor 1. J Neurosci 22:2196-2205.

Goslin K, Asmussen H, Banker G (1998) Rat hippocampal neurons in lowdensity culture. In: Culturing nerve cells, Ed 2 (Banker G, Goslin K, eds), pp 339-370. Cambridge, MA: MIT.

Hermans E, Challiss RA (2001) Structural, signalling and regulatory properties of the group I metabotropic glutamate receptors: prototypic family C G-protein-coupled receptors. Biochem J 359:465-484.

Hirose M, Kitano J, Nakajima Y, Moriyoshi K, Yanagi S, Yamamura H, Muto T, Jingami H, Nakanishi S (2004) Phosphorylation and recruitment of Syk by immunoreceptor tyrosine-based activation motif-based phosphorylation of tamalin. J Biol Chem 279:32308 -32315.

Horton AC, Ehlers MD (2003) Neuronal polarity and trafficking. Neuron 40:277-295.

Jareb M, Banker G (1998) The polarized sorting of membrane proteins expressed in cultured hippocampal neurons using viral vectors. Neuron 20:855-867.

Kim CH, Takamiya K, Petralia RS, Sattler R, Yu S, Zhou W, Kalb R, Wenthold R, Huganir R (2005) Persistent hippocampal CA1 LTP in mice lacking the C-terminal PDZ ligand of GluR1. Nat Neurosci 8:985-987.

Kim E, Sheng M (2004) PDZ domain proteins of synapses. Nat Rev Neurosci 5:771-781.

Kitano J, Kimura K, Yamazaki Y, Soda T, Shigemoto R, Nakajima Y, Nakanishi S (2002) Tamalin, a PDZ domain-containing protein, links a protein complex formation of group 1 metabotropic glutamate receptors and the guanine nucleotide exchange factor cytohesins. J Neurosci 22:1280-1289.

Kitano J, Yamazaki Y, Kimura K, Masukado T, Nakajima Y, Nakanishi S (2003) Tamalin is a scaffold protein that interacts with multiple neuronal proteins in distinct modes of protein-protein association. J Biol Chem 278:14762-14768.

Kneussel M (2005) Postsynaptic scaffold proteins at non-synaptic sites. The role of postsynaptic scaffold proteins in motor-protein-receptor complexes. EMBO Rep 6:22-27.

Kornau HC, Schenker LT, Kennedy MB, Seeburg PH (1995) Domain interaction between NMDA receptor subunits and the postsynaptic density protein PSD-95. Science 269:1737-1740.

Levi S, Logan SM, Tovar KR, Craig AM (2004) Gephyrin is critical for glycine receptor clustering but not for the formation of functional GABAergic synapses in hippocampal neurons. J Neurosci 24:207-217.

Lopez-Bendito G, Shigemoto R, Fairen A, Lujan R (2002) Differential distribution of group I metabotropic glutamate receptors during rat cortical development. Cereb Cortex 12:625-638.

Masu M, Tanabe Y, Tsuchida K, Shigemoto R, Nakanishi S (1991) Sequence and expression of a metabotropic glutamate receptor. Nature 349:760-765.

Mateos JM, Azkue J, Benitez R, Sarria R, Losada J, Conquet F, Ferraguti F, Kuhn R, Knopfel T, Grandes P (1998) Immunocytochemical localiza- 
tion of the mGluR1b metabotropic glutamate receptor in the rat hypothalamus. J Comp Neurol 390:225-233.

Mateos JM, Benitez R, Elezgarai I, Azkue JJ, Lazaro E, Osorio A, Bilbao A, Donate F, Sarria R, Conquet F, Ferraguti F, Kuhn R, Knopfel T, Grandes $P$ (2000) Immunolocalization of the mGluR1b splice variant of the metabotropic glutamate receptor 1 at parallel fiber-Purkinje cell synapses in the rat cerebellar cortex. J Neurochem 74:1301-1309.

Migaud M, Charlesworth P, Dempster M, Webster LC, Watabe AM, Makhinson M, He Y, Ramsay MF, Morris RG, Morrison JH, O’Dell TJ, Grant SG (1998) Enhanced long-term potentiation and impaired learning in mice with mutant postsynaptic density-95 protein. Nature 396:433-439.

Nadler LS, Kumar G, Nathanson NM (2001) Identification of a basolateral sorting signal for the M3 muscarinic acetylcholine receptor in MadinDarby canine kidney cells. J Biol Chem 276:10539-10547.

Naisbitt S, Kim E, Tu JC, Xiao B, Sala C, Valtschanoff J, Weinberg RJ, Worley PF, Sheng M (1999) Shank, a novel family of postsynaptic density proteins that binds to the NMDA receptor/PSD-95/GKAP complex and cortactin. Neuron 23:569-582.

Prybylowski K, Chang K, Sans N, Kan L, Vicini S, Wenthold RJ (2005) The synaptic localization of NR2B-containing NMDA receptors is controlled by interactions with PDZ proteins and AP-2. Neuron 47:845-857.

Rao A, Kim E, Sheng M, Craig AM (1998) Heterogeneity in the molecular composition of excitatory postsynaptic sites during development of hippocampal neurons in culture. J Neurosci 18:1217-1229.

Rappoport JZ, Simon SM (2003) Real-time analysis of clathrin-mediated endocytosis during cell migration. J Cell Sci 116:847-855.

Robbins MJ, Ciruela F, Rhodes A, McIlhinney RA (1999) Characterization of the dimerization of metabotropic glutamate receptors using an N-terminal truncation of mGluRlalpha. J Neurochem 72:2539-2547.

Romano C, Yang WL, O’Malley KL (1996) Metabotropic glutamate receptor 5 is a disulfide-linked dimer. J Biol Chem 271:28612-28616.

Rosales CR, Osborne KD, Zuccarino GV, Scheiffele P, Silverman MA (2005) A cytoplasmic motif targets neuroligin-1 exclusively to dendrites of cultured hippocampal neurons. Eur J Neurosci 22:2381-2386.

Ruberti F, Dotti CG (2000) Involvement of the proximal C terminus of the AMPA receptor subunit GluR1 in dendritic sorting. J Neurosci 20:RC78(1-5).

Sampo B, Kaech S, Kunz S, Banker G (2003) Two distinct mechanisms target membrane proteins to the axonal surface. Neuron 37:611-624.

Serge A, Fourgeaud L, Hemar A, Choquet D (2002) Receptor activation and homer differentially control the lateral mobility of metabotropic glutamate receptor 5 in the neuronal membrane. J Neurosci 22:3910-3920.

Shaner NC, Campbell RE, Steinbach PA, Giepmans BN, Palmer AE, Tsien RY (2004) Improved monomeric red, orange and yellow fluorescent proteins derived from Discosoma sp. red fluorescent protein. Nat Biotechnol 22:1567-1572.

Shiraishi Y, Mizutani A, Mikoshiba K, Furuichi T (2003) Coincidence in dendritic clustering and synaptic targeting of homer proteins and NMDA receptor complex proteins NR2B and PSD95 during development of cultured hippocampal neurons. Mol Cell Neurosci 22:188-201.

Silverman MA, Kaech S, Jareb M, Burack MA, Vogt L, Sonderegger P, Banker G (2001) Sorting and directed transport of membrane proteins during development of hippocampal neurons in culture. Proc Natl Acad Sci USA 98:7051-7057.

Silverman MA, Peck R, Glover G, He C, Carlin C, Banker G (2005) Motifs that mediate dendritic targeting in hippocampal neurons: a comparison with basolateral targeting signals. Mol Cell Neurosci 29:173-180.

Stowell JN, Craig AM (1999) Axon/dendrite targeting of metabotropic glutamate receptors by their cytoplasmic carboxy-terminal domains. Neuron 22:525-536.

Tadokoro S, Tachibana T, Imanaka T, Nishida W, Sobue K (1999) Involvement of unique leucine-zipper motif of PSD-Zip45 (Homer 1c/vesl-1L) in group 1 metabotropic glutamate receptor clustering. Proc Natl Acad Sci USA 96:13801-13806.

Tu JC, Xiao B, Yuan JP, Lanahan AA, Leoffert K, Li M, Linden DJ, Worley PF (1998) Homer binds a novel proline-rich motif and links group 1 metabotropic glutamate receptors with IP3 receptors. Neuron 21:717-726.

Tu JC, Xiao B, Naisbitt S, Yuan JP, Petralia RS, Brakeman P, Doan A, Aakalu VK, Lanahan AA, Sheng M, Worley PF (1999) Coupling of mGluR/ Homer and PSD-95 complexes by the Shank family of postsynaptic density proteins. Neuron 23:583-592.

Winckler B, Forscher P, Mellman I (1999) A diffusion barrier maintains distribution of membrane proteins in polarized neurons. Nature 397:698-701.

Xiao B, Tu JC, Petralia RS, Yuan JP, Doan A, Breder CD, Ruggiero A, Lanahan AA, Wenthold RJ, Worley PF (1998) Homer regulates the association of group 1 metabotropic glutamate receptors with multivalent complexes of homer-related, synaptic proteins. Neuron 21:707-716. 